\title{
Chapter 9 \\ Geopolitical Framings of Subalterity \\ in Education: Compounding \\ a Neoliberalized Welfare State
}

\author{
Ranu Basu
}

State-funded public education-long valued as a critical tool for reducing inequality, promoting economic mobility, and advocating for social justice — can have an ongoing transformative effect on the evolution of the public realm. The ideologies, policies, and practices of state-funded education distinctly shape various aspects of social justice, including the way urban spaces are produced and contested by those most vulnerable. However, researchers and the broader public are increasingly acknowledging the inability of publicly funded education systems to sufficiently address the needs of poor and marginalized groups. Within the context of this systemic shortcoming, displaced migrants - whose relegation to the subaltern already disconnects them politically, socially, and geographically from power-face conditions of extreme precarity. This chapter is drawn from a broader project exploring the challenge of displacement and spaces of refuge in the three disparate cities of Toronto, Havana, and Kolkata, where displacement is experienced in different forms. ${ }^{1}$ Its core argument highlights the dire consequences of forced mobility and immobility, a result of imperialist wars, geopolitics, hegemonic relations between nation states, and the historical legacies of colonialism; these must be given serious consideration should the field of geographies of education remain politically relevant. Given the context of pressing challenges confronting global societies, this chapter presents preliminary theoretical deliberations incorporating these themes, highlighting the geopolitical framings of subalterity ${ }^{2}$ in education and its contradictory relation with the

\footnotetext{
${ }^{1}$ The findings in Kolkata are not discussed in this chapter.

2"As a group experiencing subordination, subalterity is understood as the process of this subjectivity, conditioning the ways of being a subaltern that is constantly in an unsettled relation with the state" (Basu, 2013a, p. 261; italics in original).
}

\footnotetext{
R. Basu $(\square)$

Faculty of Liberal Arts \& Professional Studies, Department of Geography, York University, Toronto, ON, Canada

e-mail: ranubasu@yorku.ca
} 
neoliberalized welfare state. Such framings are useful if we are to seriously envision the geographies of nonviolence and peace within the spheres of education.

The first section of the chapter presents five propositions or imperatives, framing the geopolitics of subalterity in education to explore the tensions and contradictions between, on the one hand, the ideal notion of state governance and the public good and, on the other, the realities of marketized hegemony and its close connection to the violent geographies of war and displacement. The framing incorporates a spirit of praxis towards a theory for social change within the realm of schooling and education as spaces of transformation and intervention. The second section presents two very different empirical cases related to the spatial politics of displacement. In "Displacement I-Subalterity through Exile," I explore the spaces of displacement and refuge in Toronto, Canada, and the political discourses that preceded them. In "Displacement II-Subalterity through Blockade," I address the context of the economic blockade imposed on Cuba and utilize a case study to examine the effects schools have as revolutionary frontiers in Guantánamo. Both case studies allow us to reflect on the structural significance of engaging with the geopolitics of subalterity in education as a praxis-oriented theory for social change.

\section{The Geopolitics of Subalterity in Education}

The encyclopedia entry on the "Geographies of Education" reviews the complex interactions between education, space, and civil society (Basu, 2010). The geographies of education reflect the various sites and scales of opportunities available for investigating an array of diverse concerns. Educational spaces, the entry's author argues, are imbued with multiple purposes and meanings where the ideologies of the state and its corresponding discursive and material realities become discernible. This is a crucial point I will return to later on in the chapter. Critical studies within this broader realm are concerned primarily with social justice, power relations, and structural inequities relating to or emanating from the educational system. Manzer (1994) defines schools as human communities, public instruments, and political symbols, as well as the means by which people in a political democracy collectively strive for civic virtue, economic wealth, and cultural survival. Apart from its educational mandate, schools are places where neighborhood integration, social capital formation, and the fostering of civil society are ideally endorsed and contested (Basu, 2004). The city-school relationship is also intrinsically linked to the planning and sustainability of urban regions through the quality and vibrancy of its educational institutions; with the increasing rationalization of the neoliberalization of education, however, the public realm is often compromised.

\section{Subalterity of Education: Five Imperatives}

A few years ago in a paper published in the Canadian Geographer (Basu, 2013a), I argued that to research the spatialities of subalterity in education was to grapple with a differential and complicated terrain. The "political and theoretical importance 
of this conceptual framing," I argued, suggested that its "form, function, and structural significance posed a number of new challenges for those investigating social justice and rights in education" (p. 261). In a time of "global economic crisis, cultural divides, and social and political uncertainties," it was crucial to understand how subalterity was further accentuated through the impacts of neoliberalized education. In this paper, I explored how the "terrain of subalterity in education had multiplied in heterogeneous ways accentuated through the project of neoliberalism" (p. 260). I argued that unpacking these "socially, politically, or ideologicallythrough three contradictory imperatives-revealed intersecting spaces of marginality, hegemonic discourses, and complicated outcomes related to the governmentality of educational rights" (p. 261). The three contradictory imperatives discussed in this article included: (i) the premise of a state-funded educational system for a broader public, a universal good that would (ii) maintain equality and equity through proper policy driven redistribution and recognition approaches but in which such mandates would be governed through (iii) the logic of the market in a postcolonial settler/multicultural state. I argued that the act of silencing or subordinating different social groups was embedded within institutional practices and structures of power. This was the realm of subalterity reproduced through spaces of alienation and fragmentation and further legitimized and institutionalized through the rational discourses of neoliberalism. Through different case examples of subalterity and activism, I reviewed the spatialities of contestation.

One aspect that became increasingly evident in subsequent work but that has not been sufficiently theoretically addressed in the literature on the critical geographies of education is the importance of geopolitics in the subalterity of education alongside the radical question of spatial praxis for broader structural change. In this chapter, I thus extend the underlying spatial framing to include a possible fourth and fifth imperative, which allows me to take into account these political conditionings: (iv) Geopolitics in the subalterity of education is a driving force of displacement further complicated by the rationalization of neoliberalism. (v) This in turn leads to serious theoretical and political reconsiderations if we are to indeed engage in any kind of spatial praxis and solidarity for social justice and change. The conceptual framing below (Fig. 9.1) highlights the intersections and contradictions between the governance of territorialities on different scales, the hegemonic influences of neoliberalism and geopolitical regimes, and the tensions between ideal notions of the welfare state and the actual implementations through the microgeographies of school spaces. These are evident in the case studies presented below. In the instance of Canada, international geopolitical strategies and policies designed at the federal level are in contradiction with the legacy of neoliberal policies instituted by the state at the local level. In the case of Cuba, the economic ramifications of over five decades of a financial blockade by the US have constrained and severely limited the flow of resources; at the same time, the presence of the Guantánamo Naval base and detention camp against the will of the Cuban people undermines its sovereignty. I then offer politics through theory and praxis of subalterity in education as a radical alternative. 


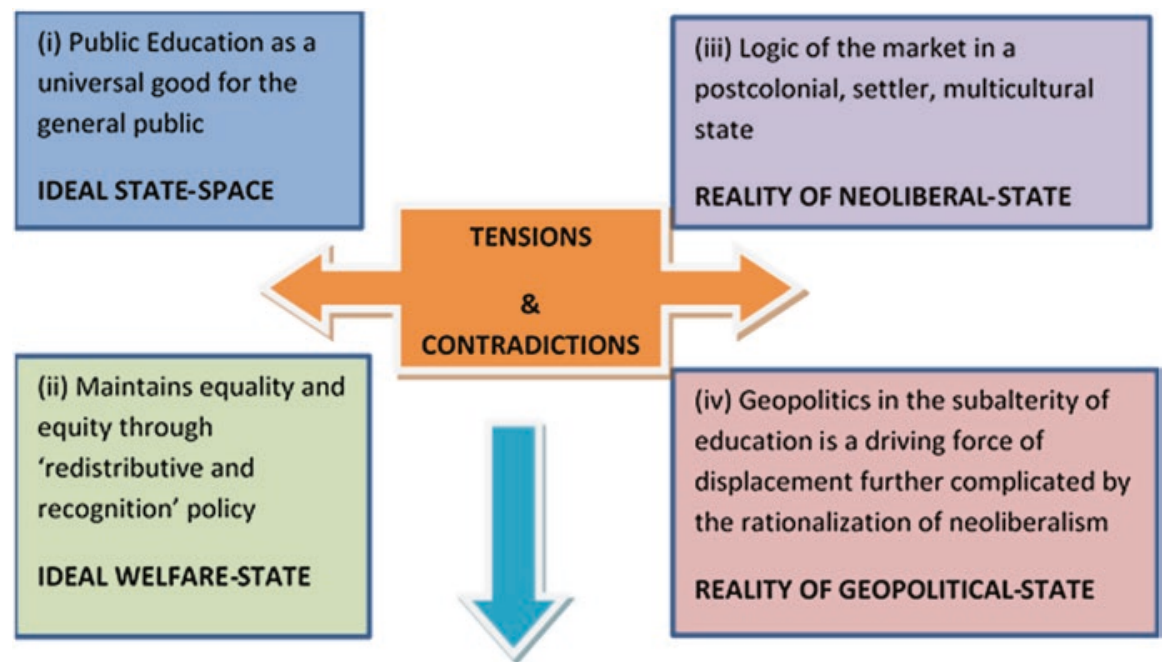

(v) Theoretical and political implications, furthering spatial praxis and solidarity for social justice

SPATIAL-PRAXIS

Fig. 9.1 Five imperatives on the subalterity of education. Source: Design by author

\section{Geopolitics and Neoliberalism}

Discussions on the linkages between geopolitics and neoliberalism are not new. In their paper "Neoliberal Geopolitics," Roberts, Secor, and Sparke (2003) connect the "geopolitical world vision" to the "neoliberal idealism of free markets, openness, and global economic integration" (p. 886). They warn against the totalizing economic narratives of neoliberalism and recommend paying attention to its "interarticulation with dangerous supplements," including the violence of American military force, alongside the presumptuous myth of the "prosperity and peace building capacity brought about by free market reforms" (p. 887). They articulate a particular kind of neoliberal geopolitics, observing that "[t]he economic axioms of structural adjustment, fiscal austerity, and free trade have now, it seems, been augmented by the direct use of military force" (p. 887) through the logics of statemanaged liberalization. Historically acknowledging that most imperial wars have been fought over economic concerns, they note that current interventions are carried out with a "much more open, systematic, globally ambitious, and quasi corporate economic style" (p. 888). As such, the geographies of such militarization and securitization are closely linked to investment capitalism and developmentalism, closely controlled by an elite minority; the market-state-civil society relations remain ambiguous. They then make the important case that neoliberal practices on a global scale have come to depend on violent interventions (p. 895) that are not solely 
restricted to war zones but are part of the workings of state institutions themselves. In fact, disposable and readily available subjects are not accidentally produced but can be traced to a chain of institutional linkages for the profit of the neoliberal state. Roberts, Secor, and Sparke note how neoliberal sites of such violence and aggression range from "maximum-security prisons [and] aggressively policed inner cities [to] workfare administration offices" (p. 894), and they note "perhaps the most exemplary site of antiliberal authoritarianism of all—Guantanamo Bay" (p. 894) —a site I will return to later on in this chapter. Such sites, they argue, "should be seen, not as exceptions to neoliberalism, but rather as neoliberalism's necessary spaces of exemption" (p. 894). Child detention centers and spaces of education for youth are not exempt from these geopolitical-neoliberal dynamics and are often used as sites of control and resistance.

\section{Feminist and Critical Geopolitics}

Aside from the logic of the market discussed above, it is important to note the strategies and techniques of governance that bind these two realms further. The neoliberal governance of such sites is aided by the biopolitical instruments and tools central to geopolitics. Hyndman highlights the feminist insights that link geopolitics closely to biopolitics. She notes that "the biometric management of outsiders with its assemblage of new laws, policies and border practices render geopolitics and biopolitics inseparable" (Hyndman, 2012, p. 246). Hyndman argues that the State's role in managing and containing migrants through the process of securitization is a "defining feature of the current state of geopolitics" (p. 243). Through a feminist geopolitical lens, she disrupts dominant thinking in the field by bringing attention to the migrants themselves rather than to the political and abstract constructs of borders that minimize, she argues, the experience of "border crossers." Within the realm of critical geopolitics, Dalby (2008) cautions that a number of elements must be carefully interrogated when exploring imperial interventions that might be considered "more hegemonic rather than dominance" (p. 430). Drawing on Joxe, Dalby (2008, from Joxe, 2002) suggests that the "mode of imperial rule defines the terms and conditions of trade and disciplines local regimes that do not follow policies broadly congruent with American financial and security interests" (p. 426). This is most explicitly evident in the case of Cuba, where the economic, commercial, and financial blockade imposed on its people by the United States continues to exist after five decades, despite being rejected 24 times by the UN General Assembly. Further, the territory illegally occupied by the US Naval Base in Guantánamo continues to challenge its sovereignty. In this case, the displacement through economic sanctions and regulations that have isolated this Caribbean island for over five decades are implemented through exclusionary policies. According to Shaw (2013), such "permanent wars" are spatial strategies used by "predatory empires." 


\section{Geopolitics and Displacement}

Geopolitical processes are most explicitly evident in the mass displacement of migrants across the globe. According to the most recent data from the UNHCR (2016a), the world is currently witnessing the highest levels of displacement on record: Nearly 34,000 people are forcibly displaced every day as a result of conflict or persecution. As of June 2016, the UNHCR reports that "an unprecedented 65.3 million people around the world have been forced from home. Among them are nearly 21.3 million refugees, over half of whom are under the age of 18 . There are also ten million stateless people who have been denied a nationality and access to basic rights such as education, healthcare, employment and freedom of movement" (2016a). Hyndman (2012) has argued that migration has long served as a "barometer of geopolitics, from human displacement generated by war to containment practices in particular territories or camps" (p. 243).

The consequences of subalterity through geopolitical displacement-whether through forced migration, exile, internal displacement, or the blockades and sanctions imposed by wars and conflict-become evident in the struggles and resistance of everyday life. The realms of education, particularly schools, often become the spaces where such daily negotiations take place. For displaced migrants, for instance, schools are frequently the first sites of the settlement experience and the collective community-building opportunity within this realm can either be inclusionary or exclusionary. School spaces are also ideological terrains where structural conditionings can be decolonized from previous histories of colonialism (Battiste, 2000).

In the following section, I turn to two very different cases related to the geopolitics of subalterity in education through the cases of exile and blockade. These cases provide an opportunity to empirically explore the framings presented in this section.

\section{Case Studies}

\section{Displacement I: Subalterity Through Exile: Neoliberal Contradictions and the Geopolitics of Displacement: Redefining Educational Spaces of Refuge in Toronto, Canada}

In 2015, Canada accepted 271,662 migrants; of these, 32,099 (11.8\%) were refugees (Government of Canada, 2017). A large proportion settles in the major urban centers of the country, making multiculturalism a largely urban phenomenon. Based on the 2011 National Household Survey, one third of the immigrants in Toronto have arrived in Canada during the past 10 years. Toronto prides itself on its identity as a "City of Diversity;" the city's residents have over 230 different ethnic origins, and over half of them were born outside of Canada. The refugees arriving in Canada during the past 10 years have come from many different parts of the world, most recently from Syria, Iraq, Sri Lanka, and Columbia. After the World War II, the 
largest single-source countries included Hungary, with an estimated 37,500 Hungarians arriving in 1956 and 1957, and Vietnam, Cambodia, and Laos, with approximately 69,000 "boat people" arriving between 1975 and 1980 (El-Assal, 2016). Canada admits five categories of refugees, their admittance based either on resettled categories from overseas or on successful refugee claims made in Canada. These refugees include government-sponsored refugees (GAR), privately sponsored refugees (PSR), blended visa office-referred refugees (BVORs), refugees landed in Canada (RLCs), and refugee dependents. The predominance of privately sponsored refugees has been critiqued to being limited to families and excluding single men, who are often perceived as security threats.

The current Canadian context has made international headlines and been influenced by geopolitical intentions and civil society interventions. When the Liberal Party under Justin Trudeau won a majority government in the October 2015 elections, he soon after announced the federal government plans to resettle 10,000 Syrian refugees by December 2015 and 35,000 by December 2016. This effort to endorse Canada's image as a peace-building nation, especially after a decade of conservative rule, was promoted as a radical initiative.

The announcement came at a time when most other countries were grappling with draconian measures such as closing borders, building fences, and confiscating assets. Furthermore, the reported death of 3-year-old Ayan Kurdi (in September 2015), who drowned while crossing from Turkey to Greece and had been denied resettlement to Canada, caused a public outcry. Communities across the country rallied for more compassionate grounds for refugee admissions. The official web site of the Liberal Party notes:

Canadians have been deeply moved by the suffering of refugees in Syria and the surrounding region. Canada has a strong history of helping those in need, from Hungarian refugees in the 1950s to Ismaili Muslim refugees in the 1970s to those fleeing South East Asia by boat in the 1970s and 1980s.

[W] will expand Canada's intake of refugees from Syria by 25,000 through immediate government sponsorship. We will also work with private sponsors to accept even more. To do this, we will invest $\$ 250$ million, including $\$ 100$ million this fiscal year, to increase refugee processing, as well as sponsorship and settlement services capacity in Canada. (Liberal, n.d.)

The admission of privately sponsored refugees, a policy unique to Canada, sparked numerous collaborative efforts among different community groups, religious and nonprofit institutions, public schools and universities, and other actors. The government anticipated that by the end of 2016, the resettlement effort could prove to be Canada's second largest from a single-source country since World War II.

Yet the importance of civil society in altering the geopolitical strategies of neoliberalism provides a framework for subaltern praxis and change. For example, in its recently published report "Global Strategy beyond Detention" (2016b), the UNHCR reports a $14 \%$ decrease in the total number of children detained across 12 countries-from 164,248 in 2014 to 141,180 in 2015. The report notes that as a result of the efforts of civil society, the two countries that were taken to court have now stopped detention. The work of the "sanctuary cities" movement in US and Canada 
has provided protection to nonstatus migrants against prosecution related to immigration law. Although successful movements like the Toronto District School Board's "Don't Ask Don't Tell" approach have allowed for nonstatus migrant children to attend school without fear of deportation, this is not a given in the Canadian context. Contradictions emerge when ideal meets reality on the ground and the politics of redistribution and recognition are brought into question. As recently as September 2016, "Education Without Borders" activists noted that as many as several thousand undocumented migrants were not eligible to attend free public school in Quebec. The legislature continues to debate this issue (News Montreal, 2016).

Discrepancies between grand federal geopolitical visions meeting the local realities of the neoliberal welfare state on the ground rattle the terms of engagement. Years of neoliberal regimes and the retrenchment of the welfare state have left most Canadian urban centers with inadequate physical and social infrastructure, in areas including affordable housing, health care, employment options, education, transit access and equity, and community centers. The large and rapid influx of refugees has thus strained settlement services in all sectors, which lack sufficient resources to adequately cope with the needs of refugees. This is particularly evident in the smaller towns across Canada where many refugees have been directed. Aside from access to settlement services, the geopolitical impacts of war and terror have had serious impacts on the health and mental well-being of students suffering from trauma and grief, including posttraumatic stress disorder (PTSD). Yet defenders of the rightwing populist explanations that currently prevail often blame the inadequacies of the state structures on the refugees themselves. This convenient shifting of blame diverts attention from the marketization of the neoliberal state or the imperialist wars that created the conditions of displacement in the first place. Decades of neoliberalization of education in Ontario, for instance, have resulted in school closures, crowded classrooms, and insufficient resources, as well as reduced funding for ESL and Special Education programs, settlement workers, and psychiatrists, among other changes. Many schools are crumbling and in disrepair, which has produced particularly difficult learning environments those in working class and migrant neighborhoods. According to a recent report released by the Ontario government and published by the Toronto Star, there is a $\$ 3.4$ million backlog in nearly 600 of Ontario schools. For 2015, the report lists 226 schools-38\% of all Toronto District School Board (TDSB) schools—as being in "critical" condition (Sachgau, 2016). In these circumstances, it is difficult for a school to function as a "community hub."

How, then, do you create a sanctuary city school system within the broader context of urban neoliberalism? How do you raise awareness that the larger geopolitical regimes of displacement compounded with the retrenchment of the neoliberal state lead to cities with structural impediments and continual exclusion? Where can the Right to the City be recognized as a radical reconditioning of social and political policy? Countering dominant narratives of insecurity, criminality, and victimhood, refugee communities themselves have over the years also responded by creating creative hubs as spaces of refuge through various grass-root initiatives. These hubs often function within the public school setting. For example, the case of multilingualism in Toronto schools has redefined meanings of "multifarious integration" 
and created Cities of Nimmathi or Peace (see Basu, 2011, 2013b). Using the example of heritage languages, this study's author demonstrated how diverse migrant students, due to the close proximity of living and studying in similar neighborhood schools, have had the opportunity to become multilingual and learn international languages with their classmates. Aside from learning an official language (English or French, a process defined as "unidirectional integration"), or language of ancestral heritage (Italian or Tamil, "mutual integration"), students were keen to learn new languages (Mandarin or Spanish, "multifarious integration"). From unidirectional to mutual to multifarious integration, the schools provided unique opportunities for the settlement process to work in ways that made migrants feel at most ease. The schools provided unique multifarious spaces where integration processes worked in informal and heterogeneous ways as a way of countering destabilizing experiences. The school in these examples often provides local institutional spaces where such power dynamics are creatively explored and become materially evident. The interactions then spilled into the public realm of the city, where common challenges of the settlement experience led to alternative social and political networks. Other subaltern resistances in Toronto that have redefined the imagination of the city have included the "Black Lives Matter" movement and indigenous responses to the "Truth and Reconciliation Report" (2015).

The spatial discrepancies between different levels of governance as indicated in the current context of the migrant crisis often bring into question the fickleness of geopolitical strategies with the more long-term effects of neoliberal governance. At the time, observers speculated that the radical response to the Syrian migrant crisis would allow Canada to play a leading role on the global stage and thereby secure a seat on the UN Security Council. The speculations were correct. In March 2016, at the UN headquarters in New York, Trudeau announced Canada's plan to seek the 2021 UN Security Council seat with a "mandate to focus on tackling climate change, helping Syrian refugees and promoting gender equality" (Harris \& Kent, 2016). Trudeau noted that his government was "determined to 'revitalize' Canada's peacekeeping efforts, support civilian institutions that prevent conflict and promote international peace and security," arguing: "This is the Canada of today, this is how we will build the world of tomorrow" (News Montreal, 2016). On August 26, 2016, the Liberals announced their commitment to provide up to 600 troops and $\$ 450$ million to UN peacekeeping missions. ${ }^{3}$ As political observers noted, Canada was seeking to be recognized as a "middle" rather than a "super" power in the new geopolitical order.

Agnew's (2001) emphasis on the distinction between "formal and practical geopolitics" (p. 30) is relevant here. This distinction becomes evident at the scalar level. On one hand, the linkage between geopolitical strategies, global displacement as a result of war and violence, and international discourses of the Canadian State (formal geopolitics) work alongside the neoliberalized retrenchment of the welfare state (practical geopolitics). The site of education is a local example of resettlement tensions and of contradictions arising and playing out in different ways (practical level).

\footnotetext{
${ }^{3}$ http://www.cbc.ca/news/politics/canada-peacekeeping-announcement-1.3736593.
} 


\section{Displacement II: Subalterity Through Blockades: Resisting Sanctions, Blockades, and the Military Base: Schools as Revolutionary Frontiers in Guantánamo, Cuba}

Since the Cuban Revolution of 1959, the economic, commercial, and financial blockade imposed on the people of Cuba by the United States has had serious detrimental effects. Despite being rejected by the UN General Assembly 24 times, the blockade continues to exist. In his State of the Union Speech of January 20, 2015, President Obama spoke of beginning to set an end to the embargo, followed by a much publicized visit to the island. Regardless of this initiative and of the resumption of flights and discussions of trade and exchange, the embargo policy continues to remain intact. A June 2015 report to the UN by the Government of Cuba describes in detail the outdated nature of the policy. Based on ten blockade laws, the report outlines the serious repercussions on the Cuban economy and consequential effects of any right to development for the Cuban people-including health, education, agriculture, infrastructure, and other sectors of the economy. The report's authors estimate the cumulative damage to amount to over 121.192 billion dollars and note the unjust nature of the policy and the deep extent of international control. The text clarifies the workings of the blockade as "not merely a bilateral issue;" its "extraterritorial nature" is further evident by "sanctions applied to third parties." The report states that announcements of December 17, 2014, act as a "violation of International Law," in particular as it relates to the "the principle of sovereign equality of States established in the Charter of United Nations" (Cuba, Report to UN, 2015, p. 37). Examples include the imposition of million dollar fines on banks and financial institutions as a result of transactions with the nation. Penalties include prohibitions on the import and export of products and services from the US, or holding accounts in any US currency at an international financial institution, including the World Bank, the IMF, and the IDB (p. 3). The laws and regulations supporting this policy, the report notes, are applied most "rigorously by US government agencies, especially by the Departments of the Treasury and Commerce and the Office of Foreign Assets Control (OFAC)" (p. 4). The report's authors regard the policy as "absurd, illegal, and morally unsustainable" and judge that "the effects of the blockade restrict Cuba's economic possibilities and harm its right to raise the living standards of its people" (p. 37). In his work on New Imperialism, Harvey (2003) called the blockade imposed on Cuba a form of violence.

Another serious point of geopolitical contention has been the demand for the return of the territory illegally occupied by the US Naval Base in Guantánamo. This base holds the infamous Guantánamo Prison, which since 2002 has held 779 prisoners from the "war on terrorism." The base's closure is a condition for the full normalization of relations. For over five decades, the Cuban government has refused to cash $\$ 4085$ annual rent checks for the military base, as a stance of sovereignty.

In November 2015, I participated in the Fourth International Seminar on Peace and for the Elimination of Foreign Military Bases held in Guantánamo, City. The 
conference was organized by the World Peace Council, the Cuban Movement for Peace and the Sovereignty of the Peoples (MOVPAZ), and the Cuban Institute of Friendship with the Peoples (ICAP), and was attended by a large international delegation. Approximately 800 military bases exist worldwide today, and the international delegates gathered to discuss the implications of military bases, war, and securitization for their local communities.

As part of the conference, cultural events were held in Guantánamo City with a special trip to Caimanera, the town closest to the military base. Caimanera has been a neighbor to the 73-square-mile US naval base since 1903, and the purpose of the trip was to hear first-hand from local residents their experiences of living in such close proximity. On the way we were greeted by rows and rows of children in school uniforms and women and men in neatly attired work clothes, many holding banners, demanding the closure of the military base from their home town, and waving flags, delighted to welcome visitors. The mayor of Caimanera along with the governor of the Province of Guantánamo presented to us an historical overview of the city, including its imperial past and role in the revolution. They proudly showcased an overview of state-funded planning and infrastructure investments, health and education initiatives, and cultural programs particularly focused on youth. We were then escorted on a tour to observe the base, followed by a community town square meeting and proclamation of the international peace resolution. Despite living in the metaphorical backyard of one of the world's most notorious prisons, efforts concentrated on cultivating a sense of stability among local communities and minimizing the impending fears. The US naval base's illegal occupation violated the territorial sovereignty of Cuba and was a constant reminder of impeding danger and violence. Further, its strategic location on a critical part of the bay hampered possibilities for any trade in the region. The looming danger of living in the shadow of imperialism is noted by Castro in his address to the Congress in Education in 1971:

... problems of a nation 90 miles from the United States threatened by planes, by warships, by the millions of imperialist soldiers and their chemical, bacteriological, conventional, and all other kinds of weapons; they are not the problems of a nation waging an epic battle against that empire that wants to sink us and blockade us on every side. No, they are not the problems that we face as an underdeveloped nation having to sustain itself under difficult conditions. They are not the problems of more than two million children and youth or of students whom we must care for, supply with textbooks, materials, pencils, clothing, shoes, furniture, desks, blackboards, audio-visual means, chalk, and quite often food-since we have nearly half a million who eat in school-and also provide with classrooms, school buildings, clothing, and shoes. No! For such men living in such an unreal world, these are not problems. They do not exist. $\left(1971^{4}\right)$.

During our visits to both Caimanera and Guantánamo City, we conference participants positively noted the strong efforts to maintain peace and harmony within the schools and local community spaces through the engagement with culture, music, dance, and solidarity. We attended many shows that included school children singing, dancing, and reciting revolutionary poetry. The messages were often ones of peace, the singers redefining their own subjectivities through joyful practices. Songs

\footnotetext{
${ }^{4}$ http://lanic.utexas.edu/project/castro/db/1971/19710501.html.
} 
of peace, poetry, Cuban dance celebrating their rich culture, and orchestras in the public square all contributed to the discussions about peace and solidarity. As Lefebvre reminds us (1991), space is political and ideological. In Cuban cities, ideological space is embedded in the landscape and further evident in the public spaces and monuments dedicated to revolutionary heroes, as constant reminders of their years of success despite the struggles.

Marxist societies such as Cuba, after all, consider ideas weapons in the class struggle, stress the function of education in particular in facilitating political indoctrination of the population, and value universal education as a way to bring about social equality. (Aguirre \& Vichot, 1998, p. 118)

Schools have countered the tense spatial relations resulting from the close proximity to the Guantánamo prison and the area's troubled history acting as crucial institutions to maintain stability and security. Spatio-historical relations are simultaneously social, geopolitical, and neoliberal. Schools were crucial to building a culture of peace and resilience.

\section{Conclusion}

In this article, I have addressed fundamental theoretical questions in the field of geographies of education by drawing on broader theoretical concepts of subalterity, geopolitics, and neoliberalization. I have previously argued that in a time of global economic crisis, cultural divides, and social and political uncertainties, an expanded notion of subalterity is crucial to understanding the underlying embedded and strategic workings of neoliberalized education (Basu, 2013a). I have used this chapter to argue that the spatialities of subalterity in education must also contend with a geopolitical framing if the question of displacement is to be addressed structurally and systematically. Whether displacement occurs through exile or blockades, it is fundamentally an act of violence that leads to dispossession and loss. Schools often form the spatial frontiers of such resistance in which the impacts of displacement are most visibly evident and in which critical consciousness can be raised for emancipatory change. In Toronto and other cities undergoing a large influx of forced migrants, the settlement experience is one of inclusion or exclusion. Schools are critical local institutions in cities of diversity and in constant flux. In Guantánamo or other cities where imperial military bases are a cause of discomfort and anxiety among local communities, or where the effects of the blockade have left local institutions in dire circumstances, the creative interventions within schools allow for consciousness building and spaces of resilience. In Cuba, schools have always been central to the project of the Revolution. Geopolitical framings on subalterity in education provide one possible direction for intervention that is both intellectually challenging and practice-oriented towards a theory of social change. As scholars in the field of geographies of education are closely investigating the realm of power and knowledge, the question of radical spatial praxis then reflects initiatives that build on protecting human rights, social justice, and peaceful societies. 


\section{References}

Agnew, J. A. (2001). Disputing the nature of the international in political geography. In J. A. Agnew (Ed.), Reinventing geopolitics: Geographies of modern statehood (pp. 29-52). HettnerLecture: Vol. 4. Heidelberg, Germany: Department of Geography, Heidelberg University.

Aguirre, B. E., \& Vichot, R. J. (1998). The reliability of Cuba's educational statistics. Comparative Education Review, 42, 118-138. https://doi.org/10.1086/447492

Basu, R. (2004). A Flyvbjergian perspective on public elementary school closures in Toronto: A question of "rationality" or "power"? Environment and Planning C: Politics and Space, 22, 423-451. https://doi.org/10.1068/c11r

Basu, R. (2010). Education, geographies of. In B. Warf (Ed.), Encyclopedia of geography (pp. 875-876). Thousand Oaks, CA: Sage.

Basu, R. (2011). Multiculturalism through multilingualism in schools: Emerging places of "integration" in Toronto. Annals of the Association of American Geographers, 101, 1307-1330. https://doi.org/10.1080/00045608.2011.579536

Basu, R. (2013a). Multiplying spaces of subalterity in education: From ideological realms to strategizing outcomes. The Canadian Geographer, 57, 260-270. https://doi.org/10.1111/cag.12029

Basu, R. (2013b). In search of nimmathi for social sustainability? Imagining, building, and negotiating spaces of peace in Toronto's diverse neighbourhoods. Canadian Journal of Urban Research, 22, 44-66. Retrieved from https://search.proquest.com/docview/1443709988?acco untid $=11359$

Battiste, M. (2000). Maintaining aboriginal identity, languages, and culture in modern society. In M. Battiste (Ed.), Reclaiming indigenous voice and vision (pp. 192-208). Vancouver, Canada: University of British Columbia Press.

Castro, F. (1971, May 1). Castro speech, resolution close education congress. Retrieved from http://lanic.utexas.edu/project/castro/db/1971/19710501.html

Cuba. (2015). On resolution 69/5 of the United Nations General Assembly entitled "necessity of ending the economic, commercial and financial blockade imposed by the United States of America against Cuba." (Report presented to the United Nations). Retrieved from http://www. cubavsbloqueo.cu/sites/default/files/INFORME\%20BLOQUEO\%202015\%20-\%20EN.pdf

Dalby, S. (2008). Imperialism, domination, culture: The continued relevance of critical geopolitics. Geopolitics, 13, 413-436. https://doi.org/10.1080/14650040802203679

El-Assal, K. (2016). 2016: A record-setting year for refugee resettlement in Canada? Retrieved from The Conference Board of Canada Website http://www.conferenceboard.ca/commentaries/immigration/default/16-02-02/2016_a_record-setting_year_for_refugee_resettlement_in_ canada.aspx

Government of Canada. (2017, March 2). Refugees and asylum: Apply for refugee status from within Canada, find out how to come to Canada as a refugee, sponsor a refugee or find refugee services in Canada. In Immigration (section 2). Retrieved from http://www.cic.gc.ca/english/ refugees/

Harris, K., \& Kent, M. (2016, March 16). Trudeau unveils Canada's plan to seek 2021 UN Security Council seat: Move plays in to PM's narrative that "Canada is back," expert says. CBC News. Retrieved from http://www.cbc.ca/news/politics/ canada-united-nations-security-council-1.3491917

Harvey, D. (2003). The new imperialism. Oxford, UK: Oxford University Press.

Honouring the Truth, Reconciling for the Future. (2015). Summary of the final report of the Truth and Reconciliation Commission of Canada. Winnipeg, Canada: The Truth and Reconciliation Commission of Canada.

Hyndman, J. (2012). The geopolitics of migration and mobility. Geopolitics, 17, 243-255. https:// doi.org/10.1080/14650045.2011.569321

Lefebvre, H. (1991). The production of space. Oxford, UK: Blackwell.

Liberal. (n.d.). Syrian refugees. Retrieved from https://www.liberal.ca/realchange/syrian-refugees/ 
Manzer, R. A. (1994). Public schools and political ideas: Canadian educational policy in historical perspective. Toronto, Canada: University of Toronto Press.

News Montreal. (2016, August 28). Activists say up to several thousand immigrant children not eligible for Quebec public schools. Retrieved from http://montreal.ctvnews.ca/activists-sayup-to-several-thousand-immigrant-children-not-eligible-for-quebec-public-schools-1.3047909

Roberts, S., Secor, A., \& Sparke, M. (2003). Neoliberal geopolitics. Antipode, 35, 886-897. https:// doi.org/10.1111/j.1467-8330.2003.00363.x

Sachgau, O. (2016, August 22). Toronto schools face $\$ 3.4$ billion repair backlog: TDSB first board in province to release detailed information on conditions of its 588 schools. The Star. Retrieved from https://www.thestar.com/yourtoronto/education/2016/08/22/toronto-schoolsfaces-34-billion-repair-backlog.html

Shaw, I. G. R. (2013). Predator empire: The geopolitics of US drone warfare. Geopolitics, 18, 536-559. https://doi.org/10.1080/14650045.2012.749241

UNHCR (The UN Refugee Agency). (2016a). Figures at a glance. In About us (section 1). Retrieved from http://www.unhcr.org/figures-at-a-glance.html

UNHCR (The UN Refugee Agency). (2016b). Beyond detention: A global strategy to support governments to end the detention of asylum-seekers and refugees. Geneva, Switzerland: United Nations High Commissioner For Refugees.

Open Access This chapter is licensed under the terms of the Creative Commons Attribution 4.0 International License (http://creativecommons.org/licenses/by/4.0/), which permits use, sharing, adaptation, distribution and reproduction in any medium or format, as long as you give appropriate credit to the original author(s) and the source, provide a link to the Creative Commons license and indicate if changes were made.

The images or other third party material in this chapter are included in the chapter's Creative Commons license, unless indicated otherwise in a credit line to the material. If material is not included in the chapter's Creative Commons license and your intended use is not permitted by statutory regulation or exceeds the permitted use, you will need to obtain permission directly from the copyright holder.

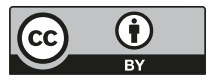

